\title{
Natalia Lytovchenko
}

Oles Honchar Dnipropetrovsk National University

\section{VISUAL ASPECT OF THE LANGUAGE TEXTBOOKS IN MULTICULTURAL EDUCATION}

\begin{abstract}
This paper is an attempt to explore some of the issues and challenges that are embedded in learning a foreign language in multicultural society. It deals with visual non-verbal textbook series for those kids who study English as a foreign language.
\end{abstract}

Key word: visual, non-verbal, textbook series, culture, paradigm.

\section{Introduction.}

Change in the functioning of the foreign languages entails a change of approach to foreign languages teaching. Many contemporary methodologists (E. M. Vereshchagin, M. N. Vyatyutnev, I. A. Zimniaia, V. G. Kostomarov, I. Ya. Lerner, O. D. Mitrofanova, E. I. Passov and others) adhere to the idea of cultural approach. According to this approach education is viewed as the transmission of ideas, achieved by the contemporary level of culture, since without culture nothing can become the content of education (I. Ya. Lerner). The actual problems of the modern education is the change of traditional knowledge-centered paradigm by culturecentered paradigm. Thus, from the formula "language + culture" we pass to the formula "language through culture and culture through the language" $[4, \mathrm{p} .10]$.

In the last 20-25 years there appeared a number of studies devoted to the problem of illustrations in textbooks. Researchers attempt to determine the nature of book illustrations and their role in the assimilation of specific educational material. It is of vital importance that in these studies there is a tendency to consider the iconic textbook material not as a sum of individual, autonomous drawings , reproductions, photographs, but as an integral component of a textbook, as the iconic series that together with the verbal part of the text comprise "single text book" [6, p. 5]..

There exists many topical issues related to the organization of the textbook. In our opinion, such issues are the nature of the fine series; peculiarity of fine range of textbooks on 
various subjects; combined effect of non-verbal forms of presentation with holding on development, education, knowledge and training; possibilities of fine mechanisms in the formation of a number of different types of speech.

Thus, the object of our study is the process of learning the English language culture in Primary school in Ukraine.

The subject is studying visual aspect of the textbooks in the process of mastering the English-speaking culture.

The aim of the article is to establish the connection between mastering the English culture and the visual non-verbal component of the textbook series.

This aim promotes a number of objectives:

Implementation of this goal required the solution of a number of problems :

1) to identify the nature of the visual component of the textbook series as a crosscultural phenomena, such as multi-level artistic sign and in accordance with this to determine its structure and component composition ;

2) to determine the number of visual function in the textbook of foreign language culture ;

3) to identify the factors affecting the adequate perception of nonverbal visual textbook series as a whole and each of its components ;

\section{Theory}

Visual non-verbal textbook series is one of the signs of culture. It is one of the possible elements of the textbook model in culture. We understand visual non-verbal series as subjectobject spatial formation carrying visually presented nonverbal art information. It is not just a sum of illustrations.

Visual nonverbal series as a sign has the following features :

- visuality as visual nonverbal series is perceived visually ;

- communicative character, since the signs are always used by people with communicative purpose, without this purpose, they are not signs, under special conditions visual nonverbal series can function as a means of communication ;

- weak conventionality, which is determined by a high degree of conditional relations between visual non-verbal signs and real life events;

- motivation form based on the visual similarity with real life realities based on such characteristics of the sign, as "arbitrary" in terms of the relationship "reality - value - the sign";

In philosophy and psychology the perception is understood as a cognitive process of sensually-shaped reflection of reality in the form of sensual image of the object [1, 2, 5 etc. ]. Perception - intermediate level $\neg$ accurate reflection between feeling and thinking. Based 
on the immediate sensations of different modalities, it performs as

In modern psychology, there are three kinds of perceptual operations. First - the operation of object detection when the most distinguished in-formative features of the object are familiar with them. In our case, we believe this feature contour images of objects, allow the barking isolate the object of study of the background. Then it is generally recognized that the colour appears as an independent phenomenon of culture, style element, life style. In the colour coded information, each colour is a definite signal to the perceiver, especially about the upcoming pleasure or displeasure, as colour perception is closely linked with emotions.

People all the time responding to the colour codes virtually every minute give colour signals.

Harmonious and disharmonious combination of colours is also a kind of culture marks. Perceiving or creating harmony, people should be able to handle colour relations. They exist in conceptual form and that it is impossible to express the images exclusively. It is known that differences in the colour coding system are caused by national or ethnic, geographical and other conditions.

Another source of child's mental development is verbal language. Its impact on the overall human development is especially effective at the age of 6-7 years, visual- figurative thinking gradually begins to give way to verbal and logical development.

\section{Method}

To achieve the aim and objectives of our research we use the following methods: the study of psychological, semiotic, pedagogical literature concerning this issue; comparing of illustrated textbooks of the English language as a foreign one; systematic and structural approach to the outlay of visual nonverbal textbook series; modeling as a method of solving the basic methodological problems associated with the operation of nonverbal visual textbook series; communicative approach, indicating the establishment of links between the perception of the spectator textbook series and verbal communication process, the principle of didactic learning that defines the leading role of mental functions and speech mechanisms, motivational and other areas of personality in the process of its formation .

\section{Discussions and results}

Visual nonverbal textbook series is a sign carrying information about, for - coded in language, its characteristics close to the language of fine arts. Visual non-verbal textbook has a structure, which includes a meaningful and expressive levels, signaling means (sensory standards) expressive level is at 
its three sublevels, forming part of a multilevel specific alphabet artistic mark.

A study in this paper, giving a theoretical basis using non-verbal visual tutorial series as a means of control and develop a practical methodology for constructing data in the number of English-language culture in the textbooks.

Nonverbal visual material as a series of social media inheritance, education, carrying coded information about the definiteness amount of social experience, serves as its textbook-shaped representative of its content the Russian-speaking culture. This content is multidimensional and includes psychological content aimed at achieving the millennium development goals.

Organized nonverbal visual textbook series is methodical function control means of mastering the English language in its culture evolved, cognitive, developmental and educational aspects:

- a means of forming actions and operations the visual, creative imagination, verbal and logical thinking, means of transferring external actions in the internal means implematization and development of semiotic, communicative, aesthetic ways.

- a means of mastering the facts of Russian culture and the formation of by - znavatelnyh interests [cognitive aspect ];

- means of shaping values [educational aspect];
- means of controlling the formation of the student as the subject of learning activities through the acquisition of its component composition, in particular, educational ᄀ governmental actions; management tool generation of speech mechanisms and mastery of skills and speech abilities of different types of speech activity means of creating situations of speech communication.

Based on the analysis of works on the theory of perception, semiotics, control theory highlighted the stages of formation of the image of Russian culture at Sun acceptance ZNR tutorial and describes management techniques to imaging on each of these stages by the organization visual non-verbal textbook levels, as well as by installations and the special tasks.

Revealed possible links of verbal and nonverbal textbook series and describes the specific methods of increasing the efficiency of data connections.

We prove that the purposeful formation of actions and operations of visual perception, creative imagination, verbal and logical thinking, action semiotic decoding information about the country, some authors of the textbook can predict the organization of visual nonverbal textbook series and through the alphabet and specific techniques for building that lay in its structure.

We prove that the construction of visual non-verbal textbook series is based in English folklore. It allows to provide information on the 
specific features of English mentality. The facts of the language culture, which is the and symbolic systems threads of different genres of English folklore, select and visualize purely English realities. These problems raise similar problems to children and present them in the form of pre-stamps discussion; exercise comparing facts and native Russian cultures.

We believe that they function as a management tool mastery of visual simultaneously that play the role of controlling formation of the first grader as the subject of educational activities. They help him/her master all the component composition of educational activity. Particularly effective influence on the visual non-verbal aspect can be when learning apprentice training actions under the condition provided that visual non-verbal aspect is organized as external support to domestic action.

Theoretically substantiated the proposition that managing $* \mathrm{~V}$ formation as the subject of a first grader learning activities at mastering the context activities in perception. Its processing, and assignment - as consequence - the mastery of objects verbal component. Attempt to prove that syncretic artistic activity adequate objectives and content textbook Englishlanguage culture as it expresses the object structure of learning activities in the methods as of the child;
- includes materialized, external action and gives you the opportunity to transfer them to the internal layout ;

- a means of stimulating the acquisition of all of the components of training activities;

- a means of cognitive, communicative , aesthetic motivation when working with visual non-verbal component ;

- acts as a necessary condition for assigning values.

The features syncretic artistic components governmental activities - artistic perception , game and application of creative activity - in the early school years, described a technique of work with visual side of the textbook called mainstream activities and impact prediction authors $\neg$ opportunities specific activities of the organization process of the visual textbook .

All told it possible to develop the methodology for constructing visual textbooks English-language culture for Primary classes should be based on the following principles:

Visual textbook organization should be subordinated to the tasks of mastering visual texts, age peculiarities perceiver visual nonverbal series pupil function within visual nonverbal series textbook and is aimed at developing mastery of objects at educational , academic aspects of Kazakhstan allocated author of a textbook in accordance with step mastery of visual non-verbal textbook series.

The main condition for the functioning of the visual non-verbal textbook series should 
become a model for the author of the textbook selection of optimal coding systems available for decoding by the perceiver. To do this, the selection of content and with the expressive means of visual non-verbal textbook series must consider the level of normed functional mechanisms and student assigned to 7 years of experience in its socio-cultural an operational manifestation.

Nonverbal visual tutorial series as homomorphic model English-language culture as an object of artistic perception must include in its structure as the facts of the English culture, selected in accordance with the task of mastering the Russian-speaking culture. b) the language of visual characters (encoding methods artistic information inherent in the culture ), c) conventional ways of expressing behaviors in language of art.

In the selection of facts in the construction of the English-speaking culture containing educational level of nonverbal visual tutorial series for national schools should be considered especially English relations and native cultures at the present stage.

Expressive visual nonverbal textbook series is constructed on the basis of the facts and phenomena of English-speaking culture, to make it meaningful level; their age perception of the subject of this age, decoding and interpreting sensor of the standards and composite connections in the part of the whole, etc.; of tasks of English-speaking culture.
In order to ensure the conditions of his visual range of functioning as an independent learning tool to communicate, it is necessary to lay in the structure composition of well-defined activities and operations to correlate with verbal next tutorial, endow it with a certain richness (single logic of building elements, story, situational), set necessary in each the volume and length of fragments oriented elements defined subject age activities.

\section{Conclusion}

In the course of research we have come to the following conclusions. First of all, visual nonverbal textbook series in the English language should be considered as a singlelayered artistic sign, representing the Englishlanguage culture.

Besides, it is of vital importance that selection and structuring of information in the visual nonverbal series should be carried out by the authors of the textbook from the standpoint of developing, i. e. successive cognitive, educational and training objectives of the process of the foreign language education and taking into account the specific features of student impact the age group, which will allow this set (assuming correct organizations of working with them in the classroom) to operate in the textbook as a means of control of mastering facilities. 


\section{References:}

Ananiev, 1977 - Ананьев Б. Г. О проблемах современного человекознания / Б. Г. Ананьев. - М.: Наука, 1977. - 379 с.

Bruner, 1962 - Брунер Дж. Процесс обучения / Дж Брунер. - М.: Прогресс, 1962 - 190 с.

Rubinshtein, 1989 - Рубинштейн С. Л. Основы общей психологии- В 2-х т. / С. Л. Рубинштейн. - Т.1.М.: Педагогика,1989. - 483 с

Vekker, 1981 - Веккер Л. М. Психологические процессы / ..- Л М. Веккер. - Л.: Изд-во ЛГУ. - т.1. 1981.- $240 \mathrm{c}$.

Venger, 1969 - Венгер Л. А. Восприятие и обучение / Л. А. Венгер - М.: Просвещение, 1969 - 340 с.

Zankov, 1975 - Занков Л. В. Метод и организация исследования / Л. В. Занков // Обучение и развитие [под ред. Л. В. Занкова] - М.: Педагогика, 1975 - С. 21-45.

Zmnyaya, 1991 - Зимняя И. А. Психология обучения иностранным языкам в школе / И. А. Зимняя. М.: Просвещение, 1991.- 222 с. 